\title{
Equine and bovine papillomaviruses from Turkish brood horses: a molecular identification and immunohistochemical study
}

\section{Özgür Kanat ${ }^{1}$, Veysel S. Ataseven ${ }^{2 *}$, Serdar Babaeski ${ }^{3}$, Fatih Derelli ${ }^{4}$, Cihan Kumaş ${ }^{5}$ Fırat Doğan², and Seval Bilge Dağalp ${ }^{6}$}

${ }^{1}$ Department of Pathology, Faculty of Veterinary Medicine, Mustafa Kemal University, Hatay, Turkey

${ }^{2}$ Department of Virology, Faculty of Veterinary Medicine, Mustafa Kemal University, Hatay, Turkey

${ }^{3}$ Karacabey Stud and Breeding Station of Turkish Jockey Club, Bursa, Turkey

${ }^{4}$ İzmit Stud and Breeding Station of Turkish Jockey Club, Kocaeli, Turkey

${ }^{5}$ Veliefendi Racehorse Hospital of Turkish Jockey Club, Istanbul, Turkey

${ }^{6}$ Department of Virology, Faculty of Veterinary Medicine, Ankara University, Ankara, Turkey

\begin{abstract}
KANAT, Ö., V. S. ATASEVEN, S. BABAESKI, F. DERELLI, C. KUMAŞ, F. DOĞN, S. BILGE DAĞALP: Equine and bovine papillomaviruses from Turkish brood horses: A molecular identification and immunohistochemical study. Vet. arhiv 89, 601-611, 2019.
\end{abstract}

\section{ABSTRACT}

Papillomaviruses have an oncogenic nature, developing benign or malignant tumours in association with the proliferation of cutaneous or mucosal epithelia in humans and animals. The objective of this study was to investigate, the genoprevalence of bovine papillomavirus (BPV) types 1 and -2 , and equine papillomavirus (EcPV) types 1, 2 and 3 in Turkish brood horses, with or without genital lesions and skin tumours, and confirmation of the equine sarcoids by several immunohistochemical markers. A total of 42 genital swabs and 6 skin tumours were collected from Thoroughbred stallions/mares in Turkey. Overall, both EcPV and BPV specific DNA amplicons sampled were detected in genital swabs from $38.1 \%$ of the brood horses tested by PCR. The prevalence of BPV-1, BPV-2 and EcPV-2 in the Turkish brood horses was $14.3 \%, 2.4 \%$ and $21.4 \%$, respectively. Furthermore, there was no significant difference between the horses that appeared to be healthy $(38.7 \%)$ and symptomatic horses $(36.4 \%)(\mathrm{P}>0.05)$. Out of the six samples obtained from the six horses that had skin tumours, BPV-1 was detected in five tissue samples and four blood samples, and only one skin tumour was found to be infected with EcPV-2. This study indicates that a high prevalence of EcPV-2 and BPV-1 was found in apparently healthy horses as well as in symptomatic cases. Additionally, the horses infected subclinically with papillomaviruses may play a significant role in the epizootiology of papillomavirus infections and lead to an increase in reproductive problems in brood horse populations.

Key words: horse; immunohistochemistry; molecular identification; papillomavirus; Turkey

\footnotetext{
*Corresponding author:

Veysel Soydal Ataseven, DVM, PhD, Department of Virology, Faculty of Veterinary Medicine, Mustafa Kemal University, Hatay, Turkey, Phone: +90 3262455845 1598; Fax: +90 3262455 704; E-mail: soydalata@hotmail.com.
} 
Ö. Kanat et al.: Equine and bovine papillomaviruses from Turkish brood horses: A molecular identification and immunohistochemical study

\section{Introduction}

Papillomaviruses (PVs) are non-enveloped viruses that consist of a circular doublestranded DNA genome, with an oncogenic nature, developing benign or malignant tumours in association with the proliferation of cutaneous or mucosal epithelia in humans and animals (BOAGERT et al., 2005; NASIR and CAMPO, 2008; ZHOU et al., 2015). Similar to other species, such as cattle (CARVALHO et al., 2012), dogs and humans (ZHOU et al., 2015), equine papillomaviruses (EcPVs) also display diversity, with seven types that range from EcPV-1 to EcPV-7 (LECIS et al., 2014). EcPVs have been identified in both asymptomatic horses (BOAGERT et al., 2012; FISCHER et al., 2014) and symptomatic horses, with aural plaques, sarcoids, genital squamous cell carcinoma (SCC), penile/vulvar intraepithelial lesions (PIN/VIN), ocular, mouth lesions and genital warts (POSTEY et al., 2007; BOAGERT et al., 2012; SYKORA et al., 2012; LANGE et al., 2013; TANIWAKI et al., 2013; FISCHER et al., 2014; VAN DEN TOP et al., 2015). Furthermore, it is well-known that bovine papillomavirus (BPV) types 1 and 2, classified as Deltapapillomavirus, can infect horses as a heterogenous host, causing common fibroblastic tumours of equids described as sarcoids (NASIR and CAMPO, 2008; BRANDT et al., 2011; NASIR and BRANDT, 2013). However, both of these BPVs have also been detected in asymptomatic horses (BOAGERT et al., 2005), and even from the peripheral mononuclear blood cells of horses with equine sarcoids (BRANDT et al., 2008).

No epidemiological investigation of papillomavirus infection in Turkish horses has yet been conducted, but some cases were reported previously, affecting licenced stock horses by veterinarians at private stud farms or horse stables in Turkey. The aim of the current study was for the first time to document the genoprevalence of papillomavirus types in licenced Turkish brood horses that are clinically healthy, or that have genital lesions, and skin tumours.

\section{Materials and methods}

Animals. A total of 42 genital swabs and 6 skin tumour samples (including blood from only 4 of them) were obtained from Turkish stock horses, which included 31 Thoroughbred mares that were clinically healthy, 11 Thoroughbreds with genital lesions (4 of them also had a mucopurulent discharge), and 6 horses with skin tumours, from a private stud farm and two breeding stations in Turkey. The genital swabs obtained from the four symptomatic stallions were sampled from the fossa glandis and the preputium. The apparently healthy horses were selected randomly from two breeding stations and were older than six years. The study was approved by the local ethics committee from Mustafa Kemal University (No.2016/11-3). 
Ö. Kanat et al.: Equine and bovine papillomaviruses from Turkish brood horses: A molecular identification and immunohistochemical study

Molecular identification. A viral nucleic acid extraction kit (Roche, Germany) was used to isolate DNA from all specimens, as described in the manufacturer's instructions. Next, PCR was performed in a $20 \mathrm{~mL}$ reaction mixture (5xHot FirePol Blend Mastermix, Solis BioDyne, Estonia) containing $2 \mathrm{~mL}$ of template DNA using BPVs 1, 2 and EcPVs 1, 2, 3 type-specific primers, as described by CARVALHO et al. (2012) and VAN DEN TOP et al. (2015). The DNA products were visualized on $1.5 \%$ agarose gel staining with ethidium bromide at $0.5 \mathrm{mg} / \mathrm{mL}$. DNA extracted from Madin-Darby bovine kidney cells was used as a negative control. The amplified DNA products were confirmed through sequence analysis.

Histopathological and immunohistochemical examination. A total of three skin tumour tissues were fixed in 10\% neutral buffered formalin, routinely processedand thenembedded in paraffin that was recently sent to our laboratory. Sections were cut to a thickness of 5 $\mu \mathrm{m}$ and were stained with haematoxylin and eosin (H\&E). For immunohistochemical (IHC) confirmation of the equine sarcoids, several immunohistochemical markers, as mentioned by BOAGERT et al. (2011), were utilized. The $5 \mu \mathrm{m}$-thick sections were placed on positively charged slides (PatoLab, P.R.C.), the sections were deparaffinised and heat-induced antigen retrieval (EnVision ${ }^{\mathrm{TM}}$ FLEX Target Retrieval Solution) was performed. The slides were briefly stained with an immunohistochemistry staining system (Combine Autostainer Link 48 with PT Link and Dako's premier reagents including staining and data transfer steps). Next, the slides were incubated with primary antibodies, using mouse monoclonal anti-human p53 protein antibodies (D07, BioGenex, Netherlands; 1:150), mouse monoclonal anti-human Ki-67 antibodies (Clone Ki-67P, Dianova, Germany; 1:350) and mouse monoclonal anti-human vimentin antibodies (V-9, BioGenex, Netherlands; 1:350). All the samples were evaluated under a light microscope. Microscopic photographs of the specimens were taken by a digital imaging system (Olympus DP12BSW, Tokyo, Japan) that was assembled in the light microscope (Olympus BX50-F4, Tokyo, Japan).

Data analysis. The statistical analysis was performed using SPSS version 14.01 (Licence Code: 9869264). The chi-square test was applied in the comparison of the horse groups with healthy appearance and those with genital lesions.

\section{Results}

Out of the 48 stock horses examined in the study, 11 had genital lesions, 31 were apparently healthy and 6 had skin tumours. Out of the six samples obtained from the six horses that had skin tumours, BPV-1 was detected in five tissue samples and four blood samples, and only one skin tumour obtained from a stallion was found to be infected with EcPV-2.

None of the genital swabs tested in this study were positive for EHV-1, EHV-3, EcPV-1 and EcPV-3 DNA using PCR. Overall, the positivity rate in the genital swabs 
Ö. Kanat et al.: Equine and bovine papillomaviruses from Turkish brood horses: A molecular identification and immunohistochemical study

sampled, for both EcPVs and BPVs, was 38.1\% (16/42). With respect to PV prevalence based on the horses' clinical status, there was no significant difference between the horses that appeared to be healthy (38.7\%) and symptomatic horses (36.4\%). Moreover, the difference in the presence of PV infections between the symptomatic horses and those with healthy appearance was also insignificant $(\mathrm{P}>0.05)$. These data are shown in Table 1 .

Table 1. Distribution of papillomavirus types according to clinical features in brood horses

\begin{tabular}{|c|c|c|c|c|c|c|}
\hline & \multicolumn{2}{|c|}{$\begin{array}{c}\text { Horses with } \\
\text { papilloma n:6 (\%) }\end{array}$} & \multicolumn{2}{|c|}{$\begin{array}{l}\text { Horses with genital } \\
\text { lesion n:11 (\%) }\end{array}$} & $\begin{array}{c}\text { Healthy horses } \\
\mathrm{n}: 31(\%)\end{array}$ & $\begin{array}{c}\text { The genital swabs } \\
\text { n:42(\%) }\end{array}$ \\
\hline Sample No. & $\begin{array}{c}\text { Papilloma } \\
\text { n: } 6(\%)\end{array}$ & $\begin{array}{c}\text { Blood } \\
\text { n: } 4(\%)\end{array}$ & $\begin{array}{c}\hat{0} \\
\mathrm{n}: 4(\%)\end{array}$ & $\begin{array}{c}\text { P } \\
\mathrm{n}: 7^{7}(\%)\end{array}$ & $\begin{array}{c}\text { P } \\
\mathrm{n}: 31(\%)\end{array}$ & \\
\hline EcPV-1 & - & - & - & - & - & - \\
\hline EcPV-2 & $1(16.7)$ & NS & - & $1(14.3)$ & $8(25.8)$ & $9(21.4)$ \\
\hline EcPV-3 & - & - & - & - & - & - \\
\hline BPV-1 & $5(83.3)$ & $4(100.0)$ & $1(25)$ & $1(14.3)$ & $4(12.9)$ & $6(14.3)$ \\
\hline \multirow[t]{2}{*}{ BPV-2 } & - & - & $1(25)$ & - & - & $1(2.4)$ \\
\hline & & & $2(50.0)$ & $2(28.6)$ & $12(38.7)$ & \\
\hline Total & \multicolumn{2}{|c|}{$6(100.0)$} & \multicolumn{2}{|c|}{$4(36.4)$} & $12(38.7)$ & $16(38.1)$ \\
\hline
\end{tabular}

NS: Non-sampled

Histopathologically, three fibroblastic type equine sarcoids were diagnosed from three of the skin tumours examined. Large, arranged, polygonal and ovoid-shaped, round and oval nuclei and prominent nucleoli were seen, and cellular pleomorphism was marked in anaplastic cells. The epidermis was absent in two equine sarcoids. In cases of equine sarcoids, acanthosis, parakeratosis, hyperkeratosis and a partially thickened epidermis, with prominent epithelial pegs due to hyperplasia, were observed in one of the fibroblastic type equine sarcoids, besides the dermal proliferation of fibroblasts, which were composed of whorls, tangles and interwoven or herringbone patterns in all the equine sarcoids (Fig. 1). Intranuclear and intracytoplasmic inclusions were observed in two of the equine sarcoids diagnosed with EcPV-2 and BPV-1, as well as in the epidermis of a tissue determined to have BPV-1. All the fibroblastic type sarcoids were ulcerated and had been secondarily infected, with an infiltration of inflammatory cells among irregular, spindle-shaped tumour cells. Leukocyte infiltration, consisting mainly of neutrophil granulocytes from inflammatory cells, was found in the partially ulcerated epidermises of two equine sarcoids. Hyperaemia and haemorrhage were also observed in the samples in which BPV-1 was detected (Fig. 2). Immunohistochemically, strong positive staining for vimentin was demonstrated in three skin tumours. Positive intranuclear reactivity with Ki-67 was present in one sample. Two sarcoids showed a clear expression of p53 protein with marked variation in the stain's intensity and distribution (Fig. 3). 
Ö. Kanat et al.: Equine and bovine papillomaviruses from Turkish brood horses: A molecular identification and immunohistochemical study

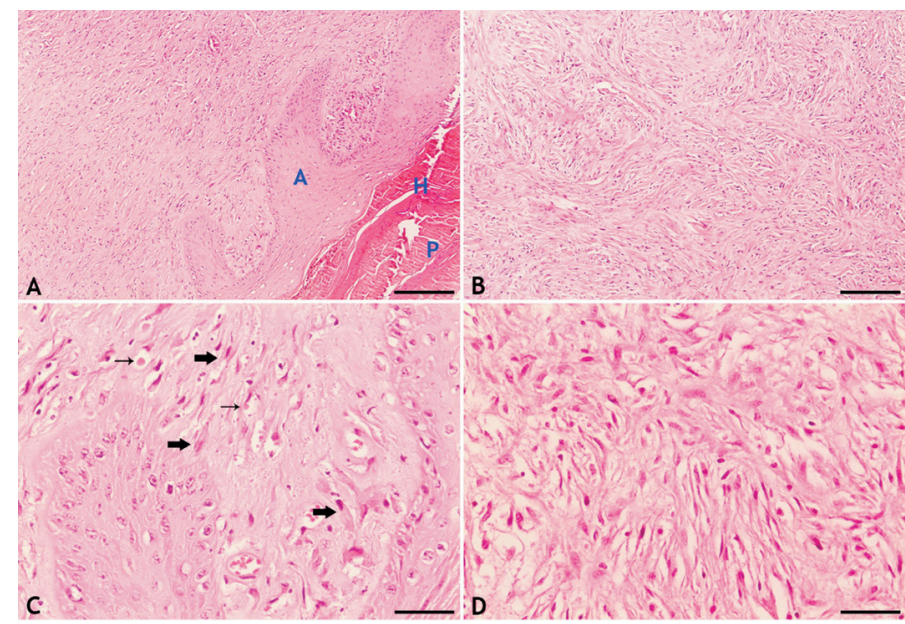

Fig. 1. Acanthosis (A), hyperkeratosis $(\mathrm{H})$, parakeratosis $(\mathrm{P})(\mathrm{A})$, Whorls, interwoven and herringbone patterns in dermal proliferation of fibroblasts (B, D), Rete peg and 'picket fence' formation (thick arrows); Intranuclear and intracytoplasmic inclusions in fibrous connective tissue and basal cells in skin layers (thin arrows) (C), Cellular pleomorphism in anaplastic cells (D). $\mathrm{H} \& \mathrm{E}$, scale bar $=200 \mu \mathrm{m}(\mathrm{A}, \mathrm{B}), 50 \mu \mathrm{m}(\mathrm{C}, \mathrm{D})$.

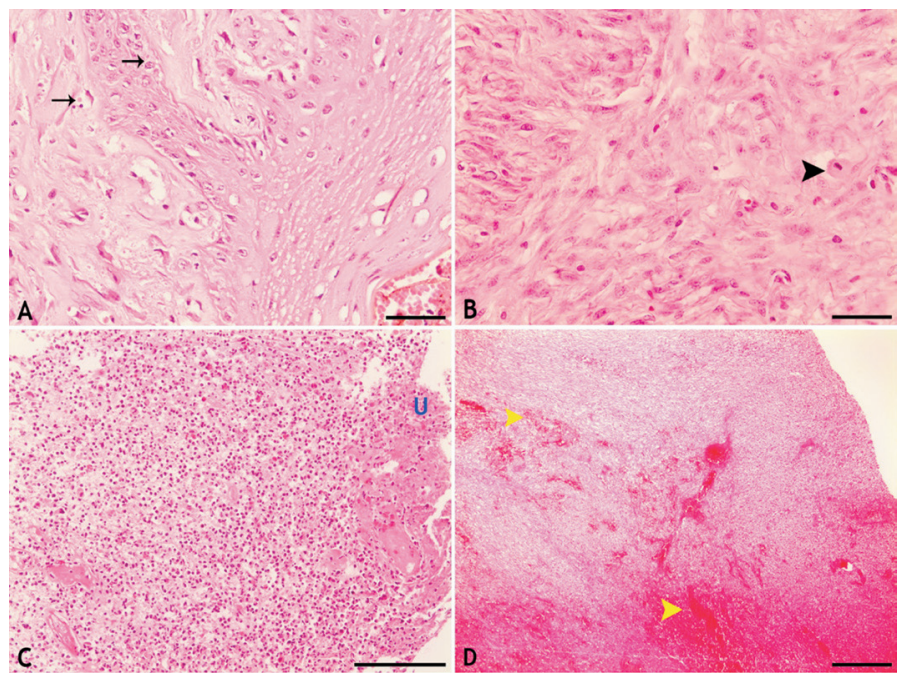

Fig. 2. Intranuclear and intracytoplasmic inclusions in fibrous connective tissue and basal cells in skin layers (thin arrows) (A), Cellular pleomorphism in anaplastic cells and mitosis in fibroblasts (arrow head) (B), Leukocyte infiltration consisting mainly of neutrophil granulocytes (star) in ulcerated epidermis (U) (C), Hyperaemia and haemorrhagie (yellow arrow heads) in dermis (D). H\&E, scale bar $=50 \mu \mathrm{m}(\mathrm{A}, \mathrm{B}), 100 \mu \mathrm{m}(\mathrm{C}), 500 \mu \mathrm{m}(\mathrm{D})$. 
Ö. Kanat et al.: Equine and bovine papillomaviruses from Turkish brood horses: A molecular identification and immunohistochemical study

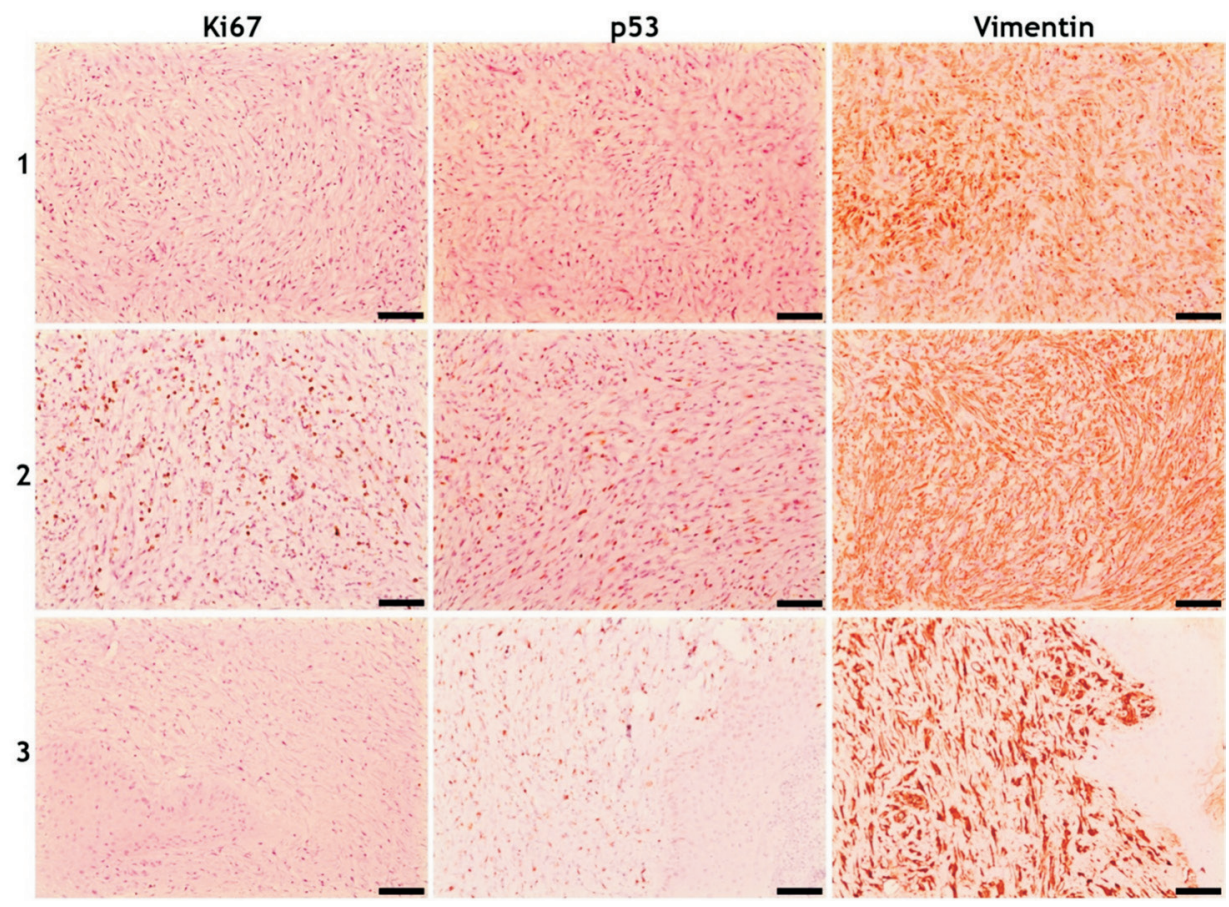

Fig. 3. Ki67: Positive intranuclear reactivity (No. 2), p53: Staining intensity and distribution (No. 2 and 3), Vimentin: Strong positive staining in all 3 samples. IHC staining, scale bar $=100 \mu \mathrm{m}$.

\section{Discussion and conclusion}

In this study, BPV-1 was detected in five of the tissues and four peripheral blood samples obtained from six brood horses with skin lesions, while EcPV-2 was identified from only one skin tumour. The reason why EcPV-2 is more significant than the other equine papillomavirus types for horse breeding is that it causes genital papillomatosis and malignant neoplasm. Moreover, EPV-2 was detected in only one stallion with a skin tumour, which later died due to a tumour-induced intestinal obstruction that we thought was metastatic after it had been clinically detected three months earlier. It has been hypothesised that direct or indirect contact with infected animals and insects may play a role in the transmission of $\mathrm{PV}$ infection in horses, although it has been reported that several co-factors, such as skin trauma, immunological weakness and genetic disposition, may play a supporting role in tumour proliferation. Furthermore, it has even been reported that similar strains or identical variations have been detected in both cattle and horses (OTTEN et al., 1993). Although we do not have specific knowledge about the presence 
of these co-factors in these horses, we recorded as anamnesis the fact that the people in charge of three stallions with skin tumours, all of which were detected to have BPV-1, were also involved in cattle breeding (Personal communication with Serdar Babaeski). Since BPV infections were also observed subclinically in the cattle, transmission to these horses may have occurred indirectly through these people, and the clinical signs that emerged later may be supported by one or more of these factors.

In this study, none of stallions with genital lesions was detected to have EcPV-2 DNA. On the other hand, clinically problematic stallions $(50 \%)$ had a higher prevalence than the clinically problematic mares (14.3\%) for BPV-1 and BPV-2. This finding may result from the lack of samples obtained from stallions. Previous researchers (BOAGERT et al., 2012; SYKORA et al., 2012; FISCHER et al., 2014) reported that the prevalence of EcPV-2 was between $2.6 \%-100 \%$ and $10 \%-36 \%$ in symptomatic and healthy-appearing horses, respectively. Additionally, smegma may also contain high amounts of infectious virions for EcPV-2 (SYKORA et al. 2017). In this study, EcPV-2 DNA was detected in only one mare with genital lesions (14.3\%), while a high prevalence of subclinical EcPV2 infection was determined in the apparently healthy mares $(25.8 \%)$. In 4 clinicallyhealthy mares whose genital swabs had EcPV-2 only, infertility or early embryonic deaths were observed during the next breeding season, occurring within two months. However, two other clinically-healthy mares, whose genital swabs were positive for EcPV-2 only, were reported to have given birth to healthy foals. It was also reported that two clinicallyhealthy mares with both BPV-1 and EcPV-2 experienced infertility during the next breeding season, while another mare with both viruses gave birth to a healthy foal, as was the case with a mare with BPV-1 only. In this study, as all mares with EcPV-2 infection were reported to have given birth to healthy foals during the breeding period in the next year, it may be hypothesised that EcPV-2 could cause transient infertility. Similarly, previous studies argue that the EcPV2 genome exhibits similar characteristics to highrisk carcinogenic human papillomaviruses (SYKORA et al. 2017), and that may lead to temporal subfertility, but rarely cancer (DEPUTY et al. 2016). Furthermore, sexual or direct contact with the lesions and vertical transmission play an important role in spreading the virus (BOAGERT et al., 2012). This infection is thought to be transmitted to other susceptible horses via horizontal or vertical routes within a breeding population, consequentially increasing the population's reproductive problems.

In this study, the histopathological changes related to equine sarcoids were similar to those reported by HALLAMAA et al. (2005) and, the epithelial rete pegs were observed to be short. A previous report suggested that the epidermis adjacent to the ulceration was always more or less hyperplastic. Moreover, the presence of BPV DNA is generally accepted as diagnostic for equine sarcoids (MARTENS et al., 2000). In the present study, two of the tissue samples detected BPV-1 and a tissue sample diagnosed with EcPV-2 
were evaluated as equine sarcoid. However, the equine sarcoids were hard to distinguish from a fibrosarcoma. Some authors have reported that all connective tissue tumours in a horse, such as fibrosarcomas, neurofibromas and fibromas, are forms of equine sarcoids (JONES et al., 1997). Especially if the distinctive epidermal component has been lost through ulceration, some sarcoids can be difficult to differentiate from fibrosarcomas or nerve sheath tumours (HENDRICK, 2017). TAYLOR and HALDORSON (2013) reported that equine sarcoids may be confused with fibromas or fibrosarcomas if the distinctive epidermal component is not visible in two of the tissues.

As immunohistochemically, a strong positive cytoplasmic staining for vimentin was demonstrated in three skin tumours in our study, as described elsewhere (BOAGERT et al. 2011). Furthermore, while displaying a clear expression of the $\mathrm{p} 53$ protein with marked variation in the stain's intensity and distribution in two of the equine sarcoids in this study found to have BPV-1, staining of p53 was not shown in one of the equine sarcoids detected to have EcPV-2. Typically playing a role in the mutation of tumour suppressor genes, p53 appears to be absent in the development of sarcoids in horses (CONSTABLE et al., 2017). In this study, Ki-67 staining in the nuclei of the dermal component was observed in only one of the equine sarcoids detected to have BPV-1, although Ki-67 staining in the dermal component showed a high variability (MARTENS et al., 2000).

In conclusion, EcPV-2, BPV-1 and BPV-2 were identified in apparently healthy horses as well as in symptomatic cases in brood horses. The present study indicates that brood horses can be infected subclinically with papillomaviruses, which may play a significant role in the epizootiology of papillomavirus infections, leading to an increase in reproductive problems of breeding horse populations. Finally, future studies on the molecular epidemiology of the PVs in Turkish brood horses are currently underway. This study will provide insights regarding future prevention and control measures for papillomavirus infections within the horse populations of breeding stations.

\section{Conflicts of interest}

The authors declared no conflicts of interest with respect to the publication of this manuscript.

\footnotetext{
Acknowledgements

This paper was presented at the $2^{\text {nd }}$ International Congress of Veterinary Microbiology on October 16-19, 2018. The authors wish to thank Ufuk KAYA, DVM and Pınar Ambarcıoğlu, MSc from "Department of Biostatistics, Faculty of Veterinary Medicine, University of Mustafa Kemal" for helping in the statistical analysis in this study.
} 
Ö. Kanat et al.: Equine and bovine papillomaviruses from Turkish brood horses: A molecular identification and immunohistochemical study

\section{References}

BOAGERT, L., A. MARTENS, C. DE BAERE, F. GASTHUYS (2005): Detection of bovine papillomavirus DNA on the normal skin and in the habitual surroundings of horses with and without equine sarcoids. Res. Vet. Sci. 79, 253-258.

BOAGERT, L., M. VAN HEERDEN, H. E. V. DE COCK, A. MARTENS, K. CHIERS (2011): Molecular and immunohistochemical distinction of equine sarcoid from schwannoma. Vet. Pathol. 48, 737-741.

DOI: $10.1177 / 0300985810377070$

BOAGERT, L., A. MARTENS, C. DE BAERE, F. GASTHUYS (2012): EcPV2 DNA in equine genital squamous cell carcinomas and normal genital mucosa. Vet. Microbiol. 158, 33-41.

DOI: $10.1016 /$ j.vetmic.2012.02.005

BRANDT, S., R. HARALAMBUS, A. SCHOSTER, R. KIRNBAUER, C. STANEK (2008): Peripheral blood mononuclear cells represent a reservoir of bovine papillomavirus DNA in sarcoid-affected equines. J. Gen. Virol. 89, 1390-1395.

DOI: 10.1099/vir.0.83568-0

BRANDT, S., R. TOBER, A. CORTEGGIO, S. BURGER, S. SABITZER, I. WALTER, C. KAINZBAUER, R. STEINBORN, L. NASIR, G. BORZACCHIELLO (2011): BPV-1 infection is not confined to the dermis but also involves the epidermis of equine sarcoids. Vet. Microbiol. 150, 35-40.

DOI: $10.1016 /$ j.vetmic.2010.12.021

CARVALHO, C. C. R., M. V. A. BATISTA, M. A. R. SILVA, V. Q. BALBINO, A. C. FREITAS (2012): Detection of bovine papillomavirus types, co-infection and a putative new BPV11 subtype in cattle. Transbound. Emerg. Dis. 59, 441-447.

DOI: $10.1111 /$ j.1865-1682.2011.01296.x

CONSTABLE, P. D., K. W. HINCHCLIFF, S. H. DONE, W. GRUNBERG (2017): Viral diseases in skin. Veterinary Medicine: A Textbook of The Diseases of Cattle, Horses, Sheep, Pigs, and Goats. $11^{\text {th }}$ ed., Elsevier Ltd., Missouri, pp. 1580-1587.

DEPUTY, C. E., J. BEERT, E. BOSMANNS, G. SALEMBIER (2016): Human Papillomavirus (HPV) virion induced cancer and subfertility, two sides of the same coin. Facts, Views and Vision in ObGyn 8, 211-222.

FISCHER, N. M., C. FAVROT, K. BIRKMANN, M. JACKSON, C. C. SCHWARZWALD, M. MULLER, K. TOBLER, M. GEISSELER, C. E. LANGE (2014): Serum antibodies and DNA indicate a high prevalence of equine papillomavirus 2 (EcPV2) among horses in Switzerland. Vet. Dermatol. 25, 210-214.

DOI: $10.1111 /$ vde. 12129

HALLAMAA, R. E., E. SAARIO, T. H. TALLBERG (2005): Macroscopical and histopathological changes in regressing primary and recurrent equine sarcoids during active specific bioimmunotherapy. In vivo 19, 761-768. 
Ö. Kanat et al.: Equine and bovine papillomaviruses from Turkish brood horses: A molecular identification and immunohistochemical study

HENDRICK, M. J. (2017): Mesenchymal tumors of the skin and soft tissues. In: Tumors in Domestic Animals. ${ }^{\text {th }}$ ed., (Mauten, D. J., Ed.), John Wiley and Sons Inc, Iowa, pp.148-150.

JONES, T. C., R. D. HUNT, N. W. KING (1997): The skin and its appendages. Veterinary Pathology. $6^{\text {th }}$ ed., (Cann, C., Ed.), Williams and Wilkins, Maryland, pp. 864-865.

LANGE, C. E., E. VETSCH, M. ACKERMANN, C. FAVROT, K. TOBLER (2013): Four novel papillomavirus sequences support a broad diversity among equine papillomaviruses. J. Gen. Virol. 94, 1365-1372.

DOI: 10.1099/vir.0.052092-0

LECIS, R., G. TORE, A. SCAGLIARINI, E. ANTUOFERMO, C. DEDOLA, C. CACCIOTTO, G. M. DORE, E. CORADDUZZA, L. GALlinA, M. BATTILANI, A. G. ANFOSSI, M. MUZZEDDU, B. CHESSA, M. PITTAU, A. ALBERTI (2014): Equus asinus Papillomavirus (EaPV1) provides new insights into equine papillomavirus diversity. Vet. Microbiol. 170, 213223.

DOI: $10.1016 /$ j.vetmic.2014.02.016

MARTENS, A., A. DE MOOR, J. DEMEULEMEESTER, R. DUCATELlE (2000): Histopathological characteristics of five clinical types of equine sarcoid. Res. Vet. Sci. 69, 295-300.

NASIR, L., M. S. CAMPO (2008): Bovine papillomaviruses: their role in the aetiology of cutaneous tumours of bovids and equids. Vet. Dermatol. 19, 243-254.

NASIR, L., S. BRANDT (2013): Papillomavirus associated diseases of the horse. Vet. Microbiol. 167, 159-167.

DOI: $10.1016 /$ j.vetmic.2013.08.003

OTTEN, N., C. VON TSCHARNER, S. LAZARY, D. F. ANTCZAK, H. GERBER (1993): DNA of bovine papillomavirus type 1 and 2 in equine sarcoids: PCR detection and direct sequencing. Arch. Virol. 132, 121-131.

POSTEY, R. C., G. D. APPLEYARD, B. A. KIDNEY (2007): Evaluation of equine papillomas, aural plaques, and sarcoids for the presence of equine papillomavirus DNA and papillomavirus antigen. Can. J. Vet. Res. 71, 28-33.

SYKORA, S., L. SAMEK, K. SCHONTHALER, F. PALM, G. BORZACCHIELLO, C. AURICH, S. BRANDT (2012): EcPV-2 is transcriptionally active in equine SCC but only rarely detectable in swabs and semen from healthy horses. Vet. Microbiol. 158, 194-198.

DOI: 10.1016/j.vetmic.2012.02.006

SYKORA, S., C. JINDRA, M. HOFER, R. STEINBORN, S. BRANDT (2017): Equine papillomavirus type 2: An equine equivalent to human papillomavirus 16 ? Vet. J. 225, 3-8.

DOI: 10.1016/j.tvj1.2017.04.014

TANIWAKI, S. A., A. J. MAGRO, A. C. GORINO, J. P. OLIVEIRA-FILHO, M. R. FONTES, A. S. BORGES, J. P. ARAUJO JR (2013): Phylogenetic and structural studies of a novel equine papillomavirus identified from aural plaques. Vet. Microbiol. 162, 85-93.

DOI: $10.1016 /$ j.vetmic.2012.08.025 
Ö. Kanat et al.: Equine and bovine papillomaviruses from Turkish brood horses: A molecular identification and immunohistochemical study

TAYLOR, S., G. HALDORSON (2013): A review of equine sarcoid. Eq. Vet. Educ. 25, 210-216.

DOI: $10.1111 / \mathrm{j} .2042-3292.2012 .00411 . x$

VAN DEN TOP, J. G. B., L. HARKEMA, C. LANGE, J. M. ENSINK, C. H. VAN DE LEST, A. BARNEVELD, P. R. VAN WEEREN, A. GRONE, A. MARTENS (2015): Expression of p53, Ki67, EcPV3 DNA, and viral genes in relation to metastasis and outcome in equine penile and preputial squamous cell carcinoma. Eq. Vet. J. 47, 188-195.

DOI: $10.1111 /$ evj.12245

ZHOU, D., J. LUFF, S. PAUL, F. ALKHILAIWI, Y. USUDA, N. WANG, V. AFFOLTER, P. MOORE, R. SCHLEGEL, H. YUAN (2015): Complete genome sequence of canine papillomavirus type 12. Genome Announc. 3, e00294-15.

DOI: 10.1128/genomeA.00294-15

Received: 9 October 2018

Accepted: 4 February 2019

\section{KANAT, Ö., V. S. ATASEVEN, S. BABAESKI, F. DERELLI, C. KUMAŞ, F. DOĞAN, S. BILGE DAĞALP: Konjski i goveđi papilomavirusi u turskih rasplodnih konja: molekularna identifikacija $\mathbf{i}$ imunohistokemijska analiza. Vet. arhiv 89, 601-611, 2019.}

\section{SAŽETAK}

Papilomavirusi su onkogene prirode, uzrokuju razvoj dobroćudnih ili zloćudnih novotvorina povezanih s proliferacijom epitela kože ili sluznica u ljudi i životinja. Cilj ovoga istraživanja bio je ustanoviti genoprevalenciju goveđeg papilomavirusa (BPV) tipa 1 i 2 i konjskog papilomavirusa (EcPV) tipa 1, 2 i 3 u turskih rasplodnih konja, s genitalnim lezijama i kožnim tumorima ili bez njih, te potvrditi sarkoide u konja pomoću nekoliko imunohistokemijskih biljega. Od kobila i pastuha pasmine engleski punokrvnjak u Turskoj prikupljena su ukupno 42 genitalna brisa i 6 kožnih tumora. Produkti DNA specifični za EcPV i za BPV, pronađeni su u genitalnim brisovima u 38,1 \% konja u uzgoju testiranih PCR-om. Prevalencija je bila: BPV-1 $14,3 \%$, BPV-2 - 2,4 \%, a EcPV-2 - 21,4\%. Nije bilo znakovite razlike ( $P>0,05)$ između konja bez simptoma $(38,7 \%)$ i onih sa simptomima (36,4 \%). Iz šest uzoraka dobivenih od šest konja koji su imali kožne tumore, BPV-1 pronađen je u pet uzoraka tkiva i četiri uzorka krvi, a samo je jedan kožni tumor bio inficiran s EcPV-2. Ovo istraživanje pokazuje da se visoka prevalencija EcPV-2 i BPV-1 može pronaći jednako i u konja koji ne pokazuju znakove bolesti i u onih koji imaju simptome. Također, supklinički inficirani konji mogu imati važnu ulogu u epizootiologiji papilomatoze te utjecati na porast reproduktivnih problema u rasplodnih konja.

Ključne riječi: konj; imunohistokemija; molekularna identifikacija; papilomavirusi; Turska

Vet. arhiv 89 (5), 601-611, 2019 
